\title{
Sports Expertise as a Predisposing Factor to Decisional Process Among Physical Education Teachers: A Case Study
}

Hiba Abdelkafi, PhD Candidate

Higher institute of education and continuing training UR ECOTIDI

(UR16ES10), Virtual University, Tunisia

Dr. Hejer Ben Jomâa, PhD

Higher institute of education and continuing training UR ECOTIDI

(UR16ES10), Virtual University, Tunisia

Higher Institute of Sport and Physical Education of Tunis, Manouba

University

UMR EFTS, Jean-Jaures Toulouse University

Salma Majdoub Chtara, PhD Candidate

Higher institute of education and continuing training UR ECOTIDI

(UR16ES10), Virtual University, Tunisia

\section{Pr. Abdelmajid Naceur, PhD}

Higher institute of education and continuing training UR ECOTIDI

(UR16ES10), Virtual University, Tunisia

\section{Pr. Georges Kpazaï, PhD}

School of Human Kinetics, Laurentian University, Sudbury (ON), Canada

Doi:10.19044/ejes.v7no3a5 URL:http://dx.doi.org/10.19044/ejes.v7no3a5

\begin{abstract}
This paper focuses on evaluating the impact of sports expertise as the embodied experience in a sports activity on the decisional process of an expert physical education teacher. Both qualitative and quantitative studies were applied within a mixed-approach using a single case study. A clinical didactics methodology was employed with three important tenses of the teaching practice (already-there, test, after-work). To understand the internal determinants that monitor the teaching practice of our participant, semistructured interview was used, in situ filmed observation and content analysis. Results indicate that personal determinants, the experiential and embodied "already-there" related to sports expertise, have a significant impact on the "personal" relationship to knowledge and the bodily awareness. This can be noticed by the way knowledge is delivered through a high recurrence to direct physical ostension demonstration by the teacher's body. Sport expertise is a
\end{abstract}


major determinant of teacher's pedagogical and didactical conducts resulting from a subjective decisional process.

Keywords: Clinical didactic, ostension, relationship to body, embodied expertise, case study.

\section{Introduction}

According to Freud (1939), teaching is an "impossible" job. It is related to "something" that is out of the control of the teacher, which affects the way he acts and is determined by the nature of those acts. This expression, inspired from the psychoanalysis field which refers to Freud (Op. Cit.) and Lacan (1977), finds its roots in the teaching practice analysis. This questions all the intern and extern elements related to the teaching process. In order to understand this particular characteristic of teaching work, the teacher must be taken into account as a singular "subject" who has his own personal path, which may have an impact on the teaching practice.

Altet (2002) and Perrenoud (1996) stated that teachers are mostly obliged to act quickly in an uncertain and unpredictable environment with a certain degree of efficacy to "face the impossible mission of transmitting the integrity of knowledge" (Terrisse, 1998). However, in situ teaching practice takes place "in a constraint and a choices system in a tensions game, which implements contradictory and paradoxical aspects, dilemmas to manage" (Altet, 2002). It is also known as "know-how constructed through the concrete, the experience and the intern construction of the teacher, in order to act in the immediacy to make decisions in singular class situations" (Noël, 1997). As a result, teachers have to mobilise all their resources in order to make efficient decisions as a matter of urgency.

This survey is interested mostly in the subjective elements which interfere and affect the teaching process of $\mathrm{PE}^{1}$ teachers. Hence, it seeks to reveal the intimate part of the teacher's personality behind all his unconscious conducts in the classroom and the way he transmits knowledge and know-how (Ben Jomâa, Sghaier, Mami, Chihi \& Kpzaï, 2017) [details removed for peer review]. This intimate part includes the "relationship to knowledge" and the "relationship to the body" which seems to be affected by a certain dimension of PE teachers known as "sport expertise". It is about understanding how this "sport expertise" may have an impact on teacher's "relationship to knowledge" and "relationship to the body" and how these personal determinants of teacher's personality affect the way knowledge is transmitted. 
The conceptual framework is implemented in both PE didactics and clinical didactics epistemological fields. This combination has proved its efficacy in teaching-practice analysis through many previous papers dealing with this subject. Thus, the aim is to study expert PE teacher's "relationship to knowledge" and "relationship to the body" developed from their embodied expertise and its eventual impact on their didactical decisions and actions, especially the ostension procedures they use to transmit knowledge.

\section{Conceptual Review} Sport Expertise

For PE teachers, sport expertise is considered as an inescapable determinant of the analysis of teaching practice (Ben Jomâa, 2009; BuznicBourgeacq, 2009; Touboul, 2011). The term "expertise" refers to "a particular aspect of physical education teacher's expertise, of his competence as a specialist of a particular discipline" (Piéron \& Carreiro Da Costa, 1995). Carnus (2001) opined that it is about the personal dimension of an expert from a "sporting point of view" determined through a long extracurricular practice (in sports clubs, sports associations, etc.) and personal profound theoretical and practical knowledge of particular sports activity. During PE lessons, PE teachers usually transmit consciously or unconsciously personal knowledge originating from their practical personal experience and their singular embodied adventure as players and/or trainers (Bodergat \& BuznicBourgeacq, 2015; Vigarello, 1982). It is about delivering “expert teachers' knowledge" (Tsangaridou, 2006) embodied in their sporting body. Thus, the first statement can be made that PE teachers are not able to transmit knowledge that is vacated from their body substance.

To reveal the implicit determinants of teachers' embodied sports expertise and its impact on their teaching practice, it is necessary to dig into their decisional already-there, i.e., their experiential and embodied alreadythere.

\section{Decisional Already-there}

Teachers' didactical actions in class are the result of a complex implicit process which is affected by numerous intern singular determinants. The historical path of the subject developed through many years of personal and professional experiences is one of the most important determinants. It emerges in the shape of conscious or unconscious acts which form different didactical phenomena. Carnus (2015) stated that in order to access the deepest layers of the subject's history, it is inescapable to resort to the "decisional alreadythere" as a clinical didactic concept which studies the subjective and personal determinants as an upstream for every decision made by the teacher. This "already-there applies a constant and latent influence on the decisional approaches of the PE teacher [...] and clarifies as well the transition from the 
intensions to the decisions" (Carnus, 2003). Some recent surveys (Carnus, 2015; Mothes, 2016) have proved that the decisional already-there has a notable impact on the different "relationships to" especially the "relationship to knowledge" and the "relationship to the body" of the teacher.

\section{Relationship to Knowledge}

The concept of the "relationship to knowledge" has emerged in educational sciences domain by psychanalysts (Beillerot, Blanchard-Laville \& Mosconi, 1996) and in PE didactics by Heuser (2009), Ben Jomâa (Op.cit.), Touboul (2011), and Carnus (2015). It is considered as the "amount of images, expectations, and judgments about the sense and social function of knowledge and school, about the taught discipline, about learning situation and oneself" (Charlot, 1982). In this study, the "relationship to knowledge" is considered as a key concept to describe, to analyse, and to understand teachers' practice.

Furthermore, three types of relationship to knowledge were developed by Chevallard (1989). The first one is the "personal" relationship to knowledge which refers to the use of personal knowledge by the teacher based on his personal experiences. The second type is the "official" relationship to knowledge. It emerges when the teacher uses official knowledge originating from official texts and documents. The last type is the "institutional" relationship to knowledge which refers to the institutional subjugations and constraints that pressure on the teacher when he is attached to a particular institution.

\section{Relationship to the Body}

In PE setting, the physical and praxeological aspect of sports practice leads to the use of the concept of the "relationship to the body" (Jourdan, 2006; Ben Jomâa, Abdelkafi, Chtara, Chihi \& Kpazaï, 2018) as another major determinant of teaching practice. This clinical concept refers to "the emotive and subjective perception that has someone regarding to his own and other's body known as an implicit me-body relationship" (Ben Jomâa et al., op. cit.). This unobservable relationship is constructed through the multiple embodied experiences of a lived teacher's body as a human being, previous student and sports player, and as a teacher. In other words, it refers to the bodily dimension of the "already-there" of the didactic subject as a form of the embodied expertise which may affect his didactical actions in class. In fact, this relationship emerges implicitly through his "doings" and his "sayings" while teaching act. Consequently, teacher's body is seen as "a lived body, professionally devoted in teaching-apprenticeship act, simultaneously a mediator and a tool, an action's author and a holder of meaning" (Jourdan, 
2006). It is implicated especially in delivering knowledge non-verbally through non-verbal knowledge and know-how ostension (Robert \& Carnus, 2013).

\section{Ostension}

In order to deliver knowledge and know-how efficiently to the students, PE teachers make use of several types of ostension including both verbal and non-verbal ones. The notion of "ostension" has firstly emerged in mathematics didactics setting in order to identify "knowledge communication practices in which the teacher provides all the constitutive elements of the targeted notion" (Ratsimba-Rajohn, 1977). In 2002, Salin's works made this notion more operational by creating an ostension procedures scale containing five types of verbal and non-verbal ostension forms (Table 1). In PE setting, Robert (2012) have adapted this notion in PE context and developed a new ostension scale inspired by Salin. In this survey, the ostension scale has been adapted based on research requirements. The new scale, which will be described in detail later, is inspired by both scales described previously in addition to the ostension scale from the work of Touboul (2011). Thus, the main purpose of studying the ostension forms used by the teacher is to see the preference of the use of one or another type of ostension based on his sports expertise.

\section{Materials and Method}

Questioning the subjective elements that interfere in teaching practice requires the use of qualitative case study which ensures a "detailed" and "indepth" (Van Der Maren, 1995) analysis of in situ teaching practice. Indeed, the survey adopts the perspective of Passeron and Revel (2005) who opt for the "rehabilitation" of the case study. For these two researchers, case studies "does not proceed without raising the question". Various studies (Op. cit.) consider that "sciences of the case have ensured the convergence between the descriptive value of clinical method and the methodological value of contextualized observation for the production of evidence". Therefore, the use of clinical didactic methodology framework in our context is quite efficient due to its authentic concepts, original data collection, and data analysis tools inspired by the Freudian and Lacanian psychoanalysis.

\section{Research Participants}

This study is about a singular case named "Nadine". "Nadine" is a PE teacher teaching in a high school in the region of Sfax in Tunisia. She is a 
handball expert as she has played for almost sixteen years and still playing with a senior female local team as a captain team until now. She played also with the Tunisian national team for ten years in different categories and participated in several international championships and world cups. This teacher has voluntarily accepted to participate in this survey and taught five PE lessons for the same ninth-grade class, including one lesson with a theme of her choice. This is in a bid to get her and the students familiar with the digital equipment and to test our experimental protocol, two lessons of gymnastics and two other lessons of handball. All the five lessons were integrally filmed.

\section{Data Collection}

The originality of this methodology lies in the use of studies of "case by case, one by one" (Terrisse, 2000). In doing so, a research ternary data collection was temporality deployed. It takes into account the didactical subject a priori and a posteriori while following his singular history and his personal experiences. It is based on three different but complementary tenses: the already-there, the test, and the after-work (see Figure 1).

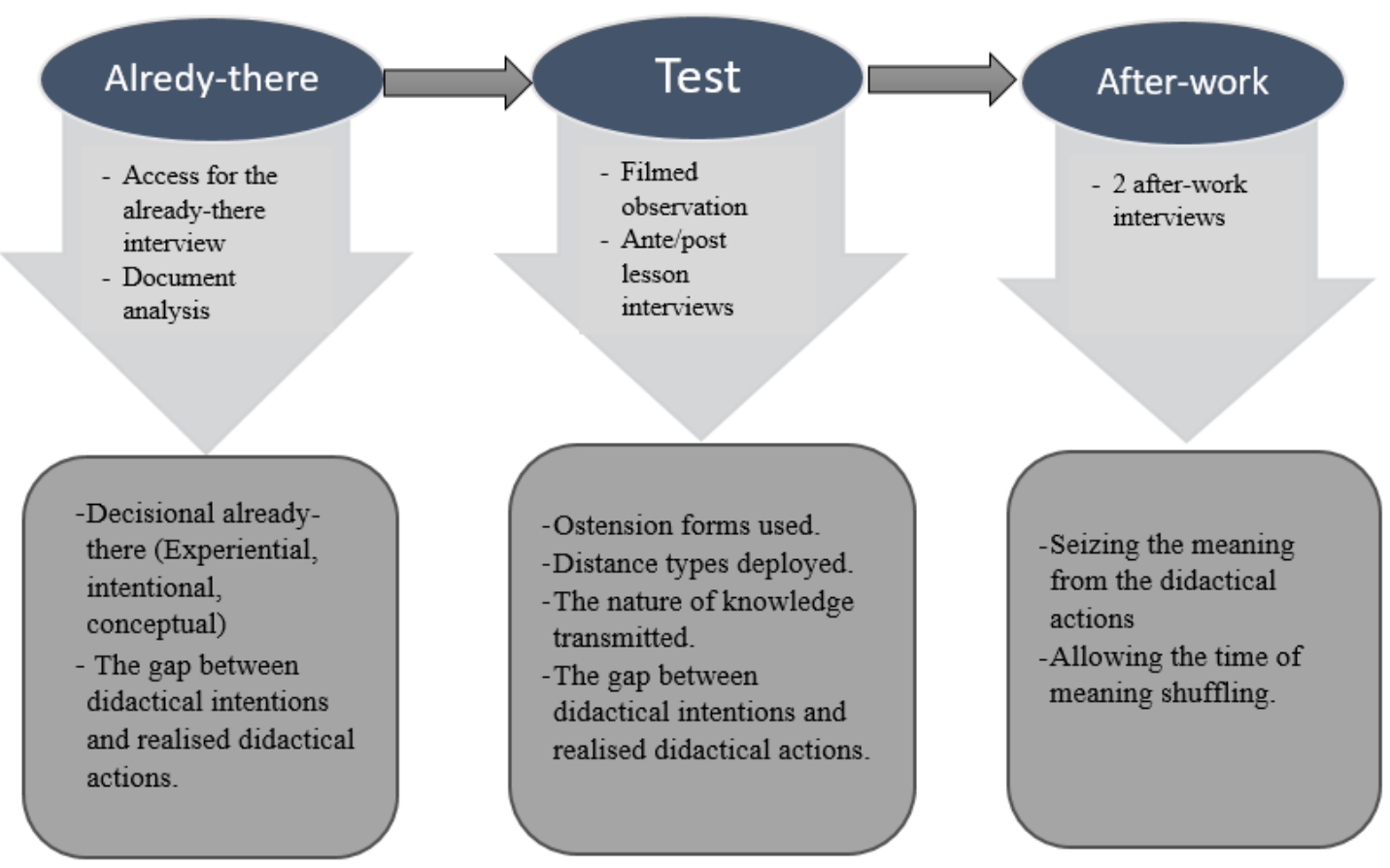

\section{Figure 1. The three tenses of the clinical didactics methodology}

For the already-there, it seeks to encompass the "inherited filters" (Loizon, 2009) of his personal, familial, and professional singular history. The 
latter is able to emerge unconsciously in the insu of the teacher subject while teaching, and it affects his decisions and his way of delivering the knowledge. These elements constitute the "decisional already-there" (Carnus \& Pédèches, 2017) which is split into three instances: the "experiential already-there", the "conceptual already-there", and the "intentional already-there". To reveal this intimate part of the subject's history, the already-there access semi-structured interview (Carnus, 2015) has been used. It is composed of different semiopened questions which allow one to dig into the deepest layers of the teacher's personality and follow his hidden history thread.

As for the second tense, the "test", it reveals the moment of the truth for the teacher when faced with the complex and contingent reality of the class context. In situ observation of four PE lessons was conducted in order to seize all the "doing" and the "saying" of the teacher in the teaching-learning process. The ethnographical observation was made using two cameras: a fixed camera to capture the integrity of the area and a mobile one focused on the teacher and follows him in all his movements and interactions. In addition to qualitative data, the filming allowed us to collect quantitative data as well. It is about the quantification of different types of ostension procedures (Salin, 2002). In this respect, data collection relies on the classification of ostensive forms (see Table 1) which is inspired by Salin's (2002) original works and is based on different recent researches in PE clinical didactic such as Buznic-Bourgeacq (2009), Touboul (2011), and Robert (2012). All the verbatim mentioned by the teacher during these lessons was recorded using a micro-lavaliere to see the knowledge communicated in didactical interactions with his students. Two types of interviews were made with the participant through the test tense: an ante-lesson interview and a post-lesson interview. This allowed the capturing of the gap between his didactical intention, his real conducts, and the feedback he makes regarding the lesson taught.

Finally, the last tense of our clinical methodology seeks to provide the time for sense shuffling. It concerns two after-work semi-structured interviews in order to have some extra explications for the teacher's practice and to extract the meaning behind some phenomena observed in the lessons filmed. It is noted that all interviews were totally recorded and transcribed by the researcher as faithful as possible to make the data treatment and analysis easier and more efficient. 


\begin{tabular}{|c|c|c|c|}
\hline Ostensive forms & \multicolumn{2}{|c|}{ Codes } & Comments \\
\hline Verbal Direct Ostension & \multicolumn{2}{|c|}{ (VDO) } & $\begin{array}{l}\text { Knowledge is explained by PE } \\
\text { teacher who does not have the } \\
\text { technical abilities or does not } \\
\text { want to demonstrate it. }\end{array}$ \\
\hline \multirow{2}{*}{$\begin{array}{l}\text { Private Physical Ostension } \\
\text { (manipulation) }\end{array}$} & Total & (TPPO) & \multirow{2}{*}{$\begin{array}{l}\text { Knowledge is transmitted to } \\
\text { the student through the } \\
\text { manipulation of his body. } \\
\text { This manipulation may be } \\
\text { either total (from the } \\
\text { beginning until the end of the } \\
\text { movement) or partial (a part } \\
\text { of the movement). }\end{array}$} \\
\hline & Partial & (PPPO) & \\
\hline \multirow{2}{*}{$\begin{array}{l}\text { Physical Direct Ostension } \\
\text { (demonstration by the teacher) }\end{array}$} & Total & (TPDO) & \multirow{2}{*}{$\begin{array}{l}\text { Knowledge is physically } \\
\text { demonstrated by the teacher's } \\
\text { body. This demonstration may } \\
\text { be total or partial. }\end{array}$} \\
\hline & Partial & (PPDO) & \\
\hline $\begin{array}{l}\text { Physical Indirect ostension } \\
\text { (demonstration by a student) }\end{array}$ & \multicolumn{2}{|c|}{ (PIO) } & $\begin{array}{l}\text { Knowledge is physically shown } \\
\text { by the means of the } \\
\text { demonstration of other students. }\end{array}$ \\
\hline Disguised Ostension & \multicolumn{2}{|c|}{ (DO) } & $\begin{array}{l}\text { Knowledge is shown through } \\
\text { either showcasing objects from } \\
\text { the "environment", or } \\
\text { questioning students about } \\
\text { these relevant objects. } \\
\text { (Linked mostly to verbal direct } \\
\text { ostension) }\end{array}$ \\
\hline No Ostension & \multicolumn{2}{|c|}{ (NO) } & $\begin{array}{l}\text { The teacher does not use any } \\
\text { form of ostension. }\end{array}$ \\
\hline
\end{tabular}

Table 1. The ostension forms retained for the survey

\section{Data Analysis}

The case study allows for a deeper analysis through the most intimate determinants that affect in one way or the other the subject's in situ practice. Based on a clinical didactic methodology, the data analysis follows the same temporality as the data collection (already-there, test, after-work). Two types of analysis were combined: a qualitative analysis using the content analysis (Van Der Marin, 1995; Bardin, 1996) known as the "most objective and trustworthy" (Berelson, 1952) method to analyse all the verbatim extracted 
from the different interviews and the lesson preparation sheets of the teacher using premade analysis grids which contain all the analysers chosen for the survey. Qualitative video analysis was made using significant screenshots of the teacher's practice as well as emerging didactical phenomena during the filmed lessons. The quantitative analysis proceeded through a data analysis software "Sphinx iQ2", which helps in making different statistics. Finally, in order to ensure better credibility and legitimacy to the results, it is important to proceed with a data triangulation method (Huberman, Miles \& De Backer, 1991). This will help to cross the findings from the three research tenses for the first time and both qualitative and qualitative analysis for the second time.

\section{Results}

The results presented are arising from both qualitative and quantitative studies. They depend on the three analysis tenses of clinical didactic methodology framework (the already-there, the test and the after-work) followed by the data triangulation and crossing in order to provide clear evidence of PE teacher's expertise effects on teaching practice.

\section{The Analysis of the Decisional Already-there of "Nadine"}

The qualitative analysis of the already-there interview (ATI) allowed the capturing of some significant elements of "Nadine's" personality and to accede to her decisional already-there. In the next paragraphs, three instances of "Nadine's" already-there will be presented with some significant extracts 2 from her verbatim during the recorded interviews.

\section{The Experiential Already-there: The "Bodily Already-there"}

The experiential already-there of teacher "Nadine" is characterised by a long and fruitful sports experience as an international professional handball player. Her extra-curricular confrontation with this sports activity, her profound knowledge, and her higher studies of handball as a specialist during her initial training have clearly proved her handball expertise. This expertise has marked her obvious dependence on sports in general and on handball in particular, as she explained: "handball is a part of me, of my daily routine, of my whole life". She added: "I cannot live without practising sports especially handball" (ATI). She considers practising handball as a source of "pleasure" and self-approval. Sports have overwhelmed her life as a teacher. Also, she is a person who has clearly marked her rich "bodily already-there" garnished with high-level physical practice. Whereas, Nadine does not have any practical experience in gymnastics besides the lessons she took in high school and university.

2 All the verbatim extract from all the interviews are mentioned in the text in the italic format. 


\section{The Conceptual Already-there}

Nadine's long handball path has affected her conceptions regarding teaching in PE in general and handball teaching in particular. Indeed, she is not convinced by the official texts of PE discipline like they are presented by the minister of youth and sports of Tunisia and refuses to apply them. "Official texts are so incoherent with the reality of the class" (ATI). She seems to be divided between what she desires to teach and what she is asked to teach (Loizon \& Carnus, 2012). She admits: "I think that the official instructions don't match what I want to teach, they severely limit my options" (ATI). As for the gymnastics context, teaching this type of sports activities presents for Nadine a source of fear and sufferance at the same time. Subsequently, her pain and insecurity feelings were clear when she claimed: "I am afraid of teaching gymnastics... it is a sports activity where there are too much risks and this tires me a lot" (ATI). In addition, she admits that she applies all the elements mentioned in the official texts in her gymnastics teaching: "in gymnastics, I mostly refer to the official instructions, I applicate what is demanded'. This shows her official teaching conception regarding knowledge related to gymnastics unlike her personal teaching conception in handball.

\section{The Intentional Already-there}

Teaching conceptions of Nadine have obviously affected her didactical intentions, especially her conception of teaching collective sports activities. Thus, she believes that handball must be taught using an "analytical" teaching method like in extracurricular training context rather the global method proposed in the official texts of PE. She explains: "I want to teach them many technical elements of handball, but it cannot be happened using a global teaching method based on games... they play games and then what? They will not learn anything" (ATI). These explanations also prove that the teacher has the intention to deliver personal knowledge originating from her handball expertise which is not mentioned in the official instructions. Otherwise, she intends to transmit official knowledge related to gymnastics: "I follow what is mentioned in the official instructions" (ATI). In addition, she admits that her fear and insecurity feelings in gymnastics teaching are behind her didactical intentions of doing aid and parade by herself. Hence, she cannot rely on her students to do so: "in gymnastics ... I do all the aids and parades for my students... they are still young I cannot trust them ... I am afraid of accidents" (ATI). For both sports activities, Nadine claims that she prefers the method of demonstration to transmit knowledge and know-how as long as she masters all of them perfectly.

\section{The Analysis of the "Test"}


In the teaching test analysis, two types of data analysis were combined: quantitative analysis through the study of the ostension procedures and qualitative analysis by seizing the meaning behind these ostension forms and the interpretation of the verbatim of both ante and post-lesson interviews.

\section{The Analysis of the Ostension Forms}

To ensure better credibility of the results, a quantitative analysis of the ostension forms was deployed in all four lessons ${ }^{3}$ taught by Nadine. This allowed having a flat sorting including all the percentages of the ostension procedures used in both handball and gymnastics lessons (Figure 2).



Figure 2. Ostension forms deployed in handball and gymnastics teaching (Sphinx iQ2)

These percentages show that the recurrence of Nadine for ostension forms is clearly divergent in both sports activities, especially in the use of total and partial physical direct ostension (PDO). In handball teaching, statistics show massive use of the PDO as a bodily dimension of different technical gesture's demonstration by $53.6 \%$ of all ostension forms including $37.7 \%$ of total demonstration (TPDO) and $15.9 \%$ of partial demonstration (PPDO). This preference of total and partial PDO shows the high implication of the teacher's body in her didactical actions. Otherwise, her use of private physical ostension (PPO) is more important in gymnastics teaching by $25.7 \%$ including $16.4 \%$ total (TPPO) and 9.3\% partial (PPPO) than handball which is $0 \%$. In addition, Nadine makes remarkable use of the non-ostension form (8.3\%) in handball

3As noted above, Nadine has taught two lessons of gymnastics and two lessons of handball which were integrally filmed and analysed. 
teaching as proof of the didactical devolution of knowledge. As for the use of $\mathrm{PIO}$, it is more important in gymnastics with $3.5 \%$ than in handball $0 \%$. This explains that Nadine uses the body of the students as a didactic support to deliver knowledge through the indirect demonstration (Screenshot 3) when she is not able to make a demonstration by herself. In handball, her high knowledge of its technical elements permits her to get in charge of the mission of knowledge transmission through TPDO and PPDO.

\section{The Relationship to Knowledge}

Nadine's teaching shows the use of different types of knowledge. In handball teaching, the knowledge transmitted was mostly personal originating from her personal experience as a professional handball player. She believes that the knowledge mentioned in the official instructions is "not sufficient for the students to learn handball" (ATI). This shows her "personal" relationship to knowledge in handball. Nevertheless, Nadine teaches gymnastics using "official" knowledge figuring in the teachers' official instructions. Her lack of knowledge in gymnastics leads her to stick to the texts as the only source and reference of knowledge in gymnastics which proves her official relationship to knowledge.

\section{The Relationship to the Body}

In this context, studying the relationship to the body of PE teachers is inescapable. A PE teacher is asked to operate on and for students' bodies by the means of his own body. Thus, Nadine supports the idea that:

Teacher's body is very useful, especially in gesture demonstrations, also for the physical appearance of PE teacher it is very important, I mean having a sporting body including his morphology, his movements, his look, his voice loudness, they play a major role in teaching actions. (ATI)

This idea was reinforced in her didactical acts notably in her massive use of gesture demonstration by the TPDO and the PPDO in both sports activities taught with remarkable preference in handball teaching (Screenshot 1). These elements prove that Nadine has an intimate relationship with her body, which is an expert sporting body with a very rich "bodily already-there". She admits: "I totally invest my body in my teaching actions, I am always on the move, I do demonstrations a lot, I also participate with my students in the games, for me it is pure pleasure" (AWI, 2). Despite her non-expertise in gymnastics, Nadine also uses her body either in PDO by demonstrating (Screenshot 2) or in PPO on one of the students who makes PIO (Screenshot 3). 


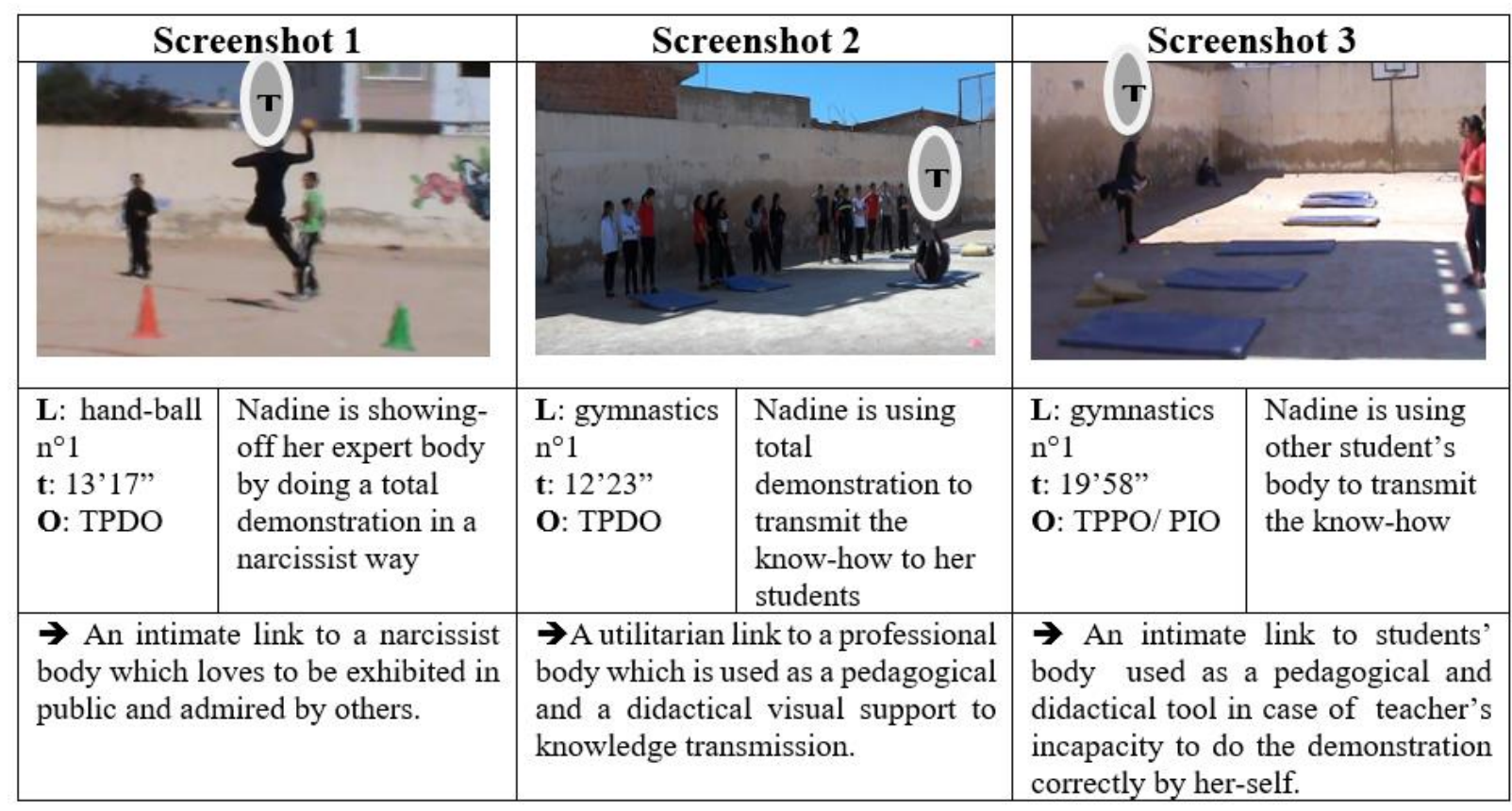

\section{T: Teacher; L: Lesson; t: time; O: Ostension}

\section{The Analysis of the After-work}

The purpose of the after-work tense is to make a return on the teacher's mostly unconscious didactical actions and to understand the hidden causes behind them. In the after-work interviews (AWI), Nadine was not completely satisfied with her handball teaching despite her high level of expertise:

In handball lessons, I am not a 100\% satisfied and I will never be... I am used to be trained in a very high level so that I cannot support teaching simple thing to debutant student who knows nothing, it drives me crazy! (AWI, 1).

This explains her high resistance to teach the knowledge mentioned in the official instruction and her recurrence to personal knowledge originating from her personal and mostly embodied experience in handball practice. Furthermore, her long bodily confrontation with this sports activity has clearly marked her way to deliver knowledge and know-how. She used the physical (bodily) demonstration of the different individual technical elements in the form of direct and partial physical direct ostension. As she explained: "it is via the bodily demonstration made by the teacher that the students can see the right gesture, know the errors and how to avoid these errors... it is a visual support to them" (AWI, 2). When she was asked why she did not demonstrate in gymnastics lessons as much as in handball, she responded:

I cannot demonstrate a gesture that I do not master perfectly... I would rather explain how it can be done verbally with a demonstration of some parts 
to clarify more the gesture or I let a student do the demonstration in front of their colleagues. (AWI, 1)

\section{Discussion}

Data triangulation method helps in confronting different types of data coming from different types of studies (qualitative and quantitative) and from different sources (Interviews, in situ observation, filming, preparation sheets, etc.). Results show that the bodily already-there of Nadine, especially in handball, have a huge impact on her relationship to knowledge, her relationship to the body, and as a result on her way to transmit knowledge and know-how by her use of ostension forms. As she admitted in the already-there interview, she considers the demonstration as the most efficient and direct way to deliver knowledge in both sports activities that she taught. However, this was proved subsequently in the quantitative study of the ostension forms that she used. Nevertheless, her use of demonstration is obviously more important in handball teaching due to her bodily expertise in this sports activity (Abdelkafi, Ben Jomâa \& Kpazaï, 2018). In fact, she tries to show her handball skills in front of her student by showing-off her expert body in a narcissist way through demonstrating very complicated gestures in public (Touboul, 2011). As for her teaching conceptions, she believes that the "structural" teaching conception (Bayer, 1979) that she is asked to use is not convincing and she prefers the "analytical" method (Parlebas, 1976; Grehaigne, 1994) for teaching the individual technical element related to non-scholar handball. This proves her "technicity conception" (Brau-Anthony, 2001) in collective sports activities teaching. She explained:

Inspectors always tell me that I am not training handball like in an extracurricular context and that I must stick to the instructions proposed in the official texts, but if I don't deliver new things to my students, why am I teaching in the first place? (ATI)

She seems to be affected by her handball expertise as her habitual way to be trained like she is used to in extra-scholar context and the use of personal knowledge in teaching.

\section{Conclusion}

In this survey, teacher's sports expertise is considered as a major determinant of teaching practice in PE setting. For Nadine, her handball expertise seems to have a huge impact on her didactical conducts, especially while teaching her sports speciality: handball. Thus, the study tried to reveal this influence by studying both implicit and explicit elements (BuznicBourgeacq, 2015) that interfere in the didactic action before, during, and after the teaching test. Sports expertise has a notable impact on Nadine's use of knowledge type in handball teaching. Also, she prefers using personal 
knowledge originating from her previous embodied practice. Her personal teaching conception indicates her "personal" relationship to knowledge through her choice of delivering personal knowledge. Therefore, in her gymnastics teaching, her lack of some knowledge and physical skills related to this sports activity led her to develop an official teaching conception and relationship to knowledge as she delivers official knowledge type coming from official texts of PE teaching.

Contrary to study expectations, for Nadine, sports and bodily expertise seems to be a double-edged sword with two contradictory faces. In fact, interviews analysis show that Nadine is subjected by the institutional requirements as she seems to be divided between what she wants to teach and what she is requested and sometimes obliged to teach. This paradox creates in her a notable pain and suffering feelings especially when it comes to the teaching of her sports speciality (handball). In addition, this division feeling also affects her relationship to the body. Thus, she seems to oscillate between a sporting expert body which is still attached to a high-level competition context where it can show-off its skills and ego, and a body of a PE teacher which is often used as a didactical and pedagogical tool for knowledge and know-how transmission. Finally, the long and rich bodily practice of Nadine has created implicit traces which emerge unwittingly during her ordinary teaching practice in class. Hence, this has affected her didactical and pedagogical conducts.

\section{Research Limitations}

Studies based on case studies have never intended to make results generalisation. It is more about bringing new elements and significant results attached to the teaching practice analysis in PE context. The main purpose is to describe, to analyse, and to understand in situ teaching practice. However, the cumulativeness of different surveys allows probably to make general and contextualized profiles in PE setting as the statement that "the most singular of personal experience may testify from the universal of all human condition" (Terrisse, 2000). From the "transferable" theoretical analysers such as the "experiential already-there" and the evaluative "after-work", the teacher's training may be enriched within new perspectives. 


\section{References:}

1. Abdelkafi, H., Ben Jomâa, H., \& Kpazaï, G. (2018). Teaching Practice between Ostension and Proximity: The Case of a Seasoned Physical Education Teacher in Clinical Didactics. International Journal of Learning, Teaching and Educational Research, 17, 2, pp. 87-98.

2. Altet, M. (2002). Une démarche de recherche sur la pratique enseignante : l'analyse plurielle (A research approach on teaching practice: the plural analysis). Revue française de pédagogie, 85-93. https://doi.org/10.3406/rfp.2002.2866

3. Bardin, L. (1996). L'analyse de contenu (The content analysis). Paris : PUF.

4. Bayer, C. (1979). L'enseignement des jeux sportifs collectifs (the collective sporting games' teaching). Paris : Vigot.

5. Beillerot, J., Blanchard-Laville, C., \& Mosconi, N. (1996). Pour une clinique du rapport au savoir. Paris : L'Harmattan.

6. Ben Jomaa, H. (2009). L'expertise dans l'enseignement de l'EPS: analyse didactique clinique de quatre professeurs (Doctoral dissertation, Thèse de doctorat non publiée, Université Paul Sabatier, Toulouse III).

7. BenJomâa, H., Sghaier, D., Mami, M., Chihi, H., \& Kpazai, G. (2017). The effect of the relationship to the knowledge of physical education teachers on ostensive forms in swimming. European Journal of Educational Sciences. 4, 4, pp. 11-23.

8. Ben Jomâa, H., Abdelkafi, H., Chihi, H., Majdoub, S., \& Kpazai, G. (2018). A Clinical Didactics Analysis of the Use of Proxemics Forms in the Teaching-Learning Process of Sports and Physical Education Setting: A Case Study in Tunisia. International Journal of Learning, Teaching and Educational Research, 17, 1, pp. 155-165.

9. Berelson, B. (1952). Content Analysis in Communication Research, The free Press. https://doi.org/10.1086/617924

10. Bodergat, J. Y. \& Buznic-Bourgeacq, P. (2015). Des professionnalités sous tension. Quelles reconstructions dans les métiers de l'humain (what construcions for human jobs?). Bruxelles : De Boeck supérieur.

11. Brau-Antony, S. (2001). Les conceptions des enseignants d'éducation physique et sportive sur l'enseignement et l'évaluation des jeux sportifs collectifs : résultats d'une enquête (the conceptions of the physical education teachers. Revue STAPS, 56, pp. 93-108. Paris : Editions AFRAPS. https://doi.org/10.3917/sta.056.0093

12. Buznic-Bourgeacq, P. (2009). La transmission du savoir expérientiel. Études de cas et analyses comparatives en didactique clinique de l'EPS. Doctoral thesis. University of Paul Sabatier, Toulouse 3. 
13. Buznic-Bourgeacq, P. (2015). Conclusion: l'apprenti, sage du métier d'enseignant, in P. Buznic-Bourgeacq \& L. Gérard. L'apprentissage du métier d'enseignant. Constructions implicites, espaces informels et interfaces de formation. 225-237. Caen: Presses Universitaires de Caen.

14. Carnus, M-F. (2001). Analyse didactique du processus décisionnel de l'enseignant d'EPS en gymnastique. Thèse de doctorat. Université Paul Sabatier. Toulouse III.

15. Carnus, M.F. (2003). Analyse didactique du processus décisionnel de l'enseignant d'EPS en gymnastique : une étude de cas croisés. In C. Amade-Escot (éd) Didactique de l'éducation physique, état des recherches, 195-224. Paris : Revue EPS.

16. Carnus, M-F. (2015). Le rapport au(x) savoir(s) du sujet-enseignant en didactique clinique de l'EPS : un « déjà-là décisionnel ». In V. Vincent \& M.-F. Carnus (dir). Le rapport au(x) savoir(s) au cœur de l'enseignement. Enjeux, richessse et pluralité . 61-73. Bruxelles : De Boeck Supérieur.

17. Carnus, M-F. \& Pédèches, P. (2017). Le rapport au savoir de l'enseignant à l'épreuve du rapport au savoir de l'apprenant. In G. Therriault, D. Baillet, M-F., V. Vincent (dir.). Rapport au(x) savoir(s) de l'enseignant et de l'apprenant : une énigmatique rencontre, 93-108. Bruxelles : De Boeck.

18. Charlot, B. (1982). Je serai ouvrier comme papa alors à quoi ça me sert d'apprendre. Echec scolaire, demarche pédagogique et rapport social au savoir, en GFEN, Quelles pratiques pour une autre école?

19. Chevallard, Y. (1989). Le concept de rapport au savoir-Rapport personnel, rapport institutionnel, rapport official. Séminaire de DidaTech, 108, 211-235.

20. Freud, S. (1939). Analyse terminée et analyse interminable, tr. fr. Rev. Fr. Psychanal, 11(1), 3-38.

21. Grehaigne, J-F. (1994). Quelques aspects bibliographiques concernant l'enseignement des sports collectifs. Dossier EPS, 17, 7-11. Paris : Editions Revue EPS.

22. Heuser, F. (2009). Chapitre 8. Du savoir enseigné en EPS au savoir de référence de l'enseignant. Étude didactique Clinique en karaté. In Didactique clinique de l'éducation physique et sportive (EPS), 133143. Bruxelles : De Boeck Supérieur.

23. Huberman, A. M., Miles, M. B., \& De Backer, C. (1991). Analyse des données qualitatives : recueil de nouvelles méthodes, 88-138. Bruxelles : De Boeck Université. 
24. Jourdan, I. (2006). Rapport au corps, rapport aux activités physiques, sportives et artistiques et logique professionnelle : deux études de cas en formation initiale en EPS. https://doi.org/10.4267/2042/16792

25. Lacan, J. (1977). Ouverture de la section clinique. Ornicar, 9,7-14.

26. Loizon, D. (2009). Les filtres personnels dans l'action didactique : étude de cas dans l'enseignement du judo. In A. Terrisse \& M.-F. Carnus (Eds), Didactique clinique de l'EPS: quels enjeux de savoirs? 63-79. Bruxelles : De Boeck Université.

27. Loizon, D. \& Carnus, M.-F. (2012). Le déjà-là décisionnel chez les enseignants novices en EPS. Un outil pour comprendre la réalité de leurs enseignements. In G. Carlier, C. Borges, M. Clerx \& C. Delens. Identité professionnelle en éducation physique. Parcours des stagiaires et enseignants novice, pp. 199-215. Louvain-la-Neuve : Presses Universitaires de Louvain.

28. Mothes, P. (2016). Quand l'analyse didactique clinique des pratiques évaluatives révèle les ressorts du désir d'enseigner : étude de cas en français et en mathématiques dans le premier degré (cycle 3). Doctoral dissertation, Université Toulouse le Mirail-Toulouse II.

29. Noël, J. (1997). L’analyse des pratiques éducatives, un cadre éthique et symbolique pour éduquer le regard de l'enseignant. Recherche et Formation, 24, 49-70. Paris : https://doi.org/10.3406/refor.1997.1394

30. Parlebas, P. (1976). Activités Physiques et éducation motrice. Paris : Editions Revue EPS.

31. Perrenoud, P. (1996). Enseigner : agir dans l'urgence, décider dans l'incertitude; savoirs et compétences dans un métier complexe. Paris, ESF

32. Piéron, M. \& Carreiro Da Costa, F. (1995). L'expertise dans l'enseignement des activités physiques et sportives. Revue de l'éducation physique, 35, 159-172.

33. Ratsimba-Rajohn, H. (1977). Étude didactique de l'introduction ostensive des objets mathématiques. Memoria de Diplomado de Estudios a Profundidad en Didáctica de Matemáticas. Universidad de Burdeos $I$.

34. Robert, M. (2012). L'ostension non verbale en EPS : Analyse didactique clinique des pratiques gestuelles de deux enseignants aux profils contrastés lors de l'enseignement de la rotation avant. Mémoire en Master 2 recherche Éducation, Formation, Travail et Savoirs, UTM.

35. Robert, M. \& Carnus, M-F. (2013). Les formes ostensives non verbales en gymnastique constitutives de la signature professionnelle de deux enseignants d'EPS. In M-F. Carnus \& A.Terrisse. Didactique clinique de l'EPS : le sujet aenseignant en question. Paris : Éd. EPS. 
36. Salin, M. H. (2002). Les pratiques ostensives dans l'enseignement des mathématiques comme objet d'analyse du travail du professeur. Venturini, Amade-Escot, Terrisse, Études des pratiques effectives : l'approche des didactiques. Grenoble : La Pensée Sauvage.

37. Terrisse, A. (1998). Transposition didactique et prise en compte du sujet : perspectives de recherche en éducation physique et sportive. In C. Amade-Escot, J.-P. Barrué, J.-C. Bos, F. Dufor, M. Dugrand \& A. Terrisse. Recherches en EPS, bilan et perspectives, 81-90. Paris : Editions Revue EPS.

38. Terrisse, A. (2000). Epistémologie de la recherche clinique en sports de combat. Recherches en sports de combat et en arts martiaux, 95108.

39. Touboul, A. (2011). Les effets de l'expérience et de l'expertise dans les pratiques enseignantes en EPS : étude didactique clinique en Savate Boxe Française (Doctoral dissertation, Université Toulouse le Mirail-Toulouse II).

40. Tsangaridou, N. (2006). Teachers' beliefs. Sage Publications.

41. Van der Maren, J. M. (1995). Méthodes de recherche pour l'éducation (Vol. 6). De Boeck Supérieur.

42. Vigarello, G. (1982). Les vertiges de l'intime. In Le corps entre illusions et savoirs. Revue Esprit, 2. Paris: Editions revue Esprit. 